\title{
A PSZICHOLÓGIAI SZAKIRODALMI FELDOLGOZÁS TÁMOGATÁSA A HÁLÓZATELEMZÉS MÓDSZERÉVEL: A TANÁCSADÁS PSZICHOLÓGIÁJÁNAK LEHETSÉGES TAXONÓMIÁJA
}

\author{
CZABÁN CSABA ${ }^{1 *}$ - NAGYBÁNYAI-NAGY OLIVÉR ${ }^{2}$ \\ ${ }^{1}$ Budapesti Múszaki és Gazdaságtudományi Egyetem, Ergonómia és Pszichológia Tanszék, \\ Budapest, Magyarország \\ ²Károli Gáspár Református Egyetem, Általános Lélektani és Módszertani Tanszék, \\ Budapest, Magyarország \\ E-mail: czaban.csaba@gtk.bme.hu
}

Benyújtva: 2021. február 17. - Elfogadva: 2021. július 28.

\begin{abstract}
A pszichológia tudományának vizsgálati területei rendkívül sokszinüek, áttekinthetôségük, belsố strukturáltságuk megértése sokszor igen komplex feladat, azonban ennek témakörtól függetlenül megkerülhetetlen lépése a szakirodalom-gyüjtés. Az átfogó jellegú szakirodalmak feldolgozása során alapvetôen két fó irányba indulhatunk, egyrészt a kvalitatív jellegú narratív összefoglalók, másrészt pedig a kvantitatív jellegú metaanalizisek áttekintését végezhetjük el. A vizsgált terület fogalmi rendszerének feltárását, integrálását az itt bemutatandó hálózatelemzési módszerünk hatékonyan képes támogatni, hiszen nem csak a globális megértés terén, hanem a kutatási fókusz specifikált, új részterületek felé való orientálásában is segítséget nyújthat. Tanulmányunkban a pszichológiai tanácsadás témakörének példáján vezetjük végig ennek folyamatát, egyrészt egy automatizált (web-scraping) adatgyüjtést, másrészt az igy kapott adatokon pedig egy hálózatelemzést elvégezve. Eredményként a modularitásalapú közösségdetekció révén a pszichológiai tanácsadás szakirodalmából kirajzolódó hálózatnak a legfontosabb témakörcsoportjait képesek voltunk beazonosítani. Összességében négy fó hálózatfragmentumot kaptunk, ezek a "földrészek" képezhetik a pszichológiai tanácsadás világtérképének alapját.
\end{abstract}

Kulcsszavak: hálózatelemzés, hálózatkutatás, közösségdetekció, modularitás, szakirodalom-gyüjtés, szakirodalmi áttekintés, pszichológiai tanácsadás

${ }^{*}$ Levelezô szerzô

(C) 2021 A szerzố(k) 


\section{BEVEZETÉS}

Jelen publikációban egy esettanulmányon keresztül vizsgáljuk a hálózatelemzés létjogosultságát kutatásmódszertani területen. Ha elhangzik a kérdés, hogy hogyan kapcsolódhat a hálózatelemzés a kutatásmódszertan folyamatához, a nem túl egzakt, ám annál kézenfekvốbb válasz, hogy minden bizonnyal számos ponton. E kapcsolódások közül mi egyet ragadunk ki, ez pedig az irodalomkutatás, vagyis egy adott témához kapcsolódó szakirodalmi források módszeres feltárása és szisztematikus feldolgozása.

Megjegyzendô, hogy a szakirodalmi áttekintésnek két megközelítése van: a narratív összefoglaló (kvalitatív jellegú) és a metaanalízis (kvantitatív jellegú). Bármilyen témáról is legyen szó, nem megkerülhetô, hogy - a szakirodalmak révén - tájékozódjunk. Mertens (2010) a kvalitatív szakirodalmi áttekintést illetően úgy fogalmaz, hogy annak célja, hogy átfogó keretet nyújtson az olvasó számára arról, miként illeszkedik az aktuális írás abba az átfogó képbe, amely a témához köthetô korábbi kutatások révén formálódott. Boote és Beile (2004) szerint pedig a kvalitatív szakirodalmi áttekintés sikerének egyik fố kritériuma - egyben értékméróje -, hogy a szerzó képes-e arra, hogy az általa vizsgált témát a tágabb tudományos szakirodalomban helyezze el. Vagyis lényegében egy lokalizációról van szó, amelyben - meglátásunk szerint - egy „térkép” mindig hasznos segédeszköz lehet.

Maga a hálózat felfogható egy speciális térképként, és mint ilyen, alkalmas arra, hogy egy-egy tudományos téma (akárcsak a földrajzi térképen pl. ország) helyét meghatározzuk, ezt követôen pedig vizsgáljuk egyéb témakörökkel (országokkal) való kapcsolódásait. Ám abban az esetben is indokolt az alkalmazása, amennyiben nem egy kisebb témakörön van a fókusz, hanem ennél átfogóbb a merítés: egy teljes szakterület komplex rendszerként való felvázolása, majd e terület dekomponálása a cél, különbözô alterületekre. Ez nagyjából megfeleltethetô annak, amikor kezünkbe vesszük egy kontinens térképét, amelyen nincsenek feltüntetve az országhatárok, és ránk hárul a feladat, hogy azokat megrajzoljuk. Az elóbbi példa egyfajta induktív logikát követ, mivel egy adott specifikus, konkrét részegységből kiindulva kíséreljük meg feltérképezni annak kapcsolatait. Az utóbbi ezzel szemben egy deduktív jellegú eljárás, hiszen ebben az esetben adott egy nagyobb, általánosabb rendszer, és a célkitúzésünk az, hogy egyfajta visszakövetkeztetést tegyünk ennek a rendszernek az „építôkockáira”.

Bármelyik logikára is essen a választásunk, a hálózatelemzés módszere támpontként szolgálhat az információgyújtésben, vagyis tulajdonképpen egyfajta orientáló funkciója van a tudományos megismerés során. Nem állítjuk azt, hogy a szakirodalmi áttekintés esetében a hálózatelemzés alkalmazása feltétlenül szükséges. Csupán azt valljuk, hogy a módszer egy hasznos kiegészítô segédeszköz, amely új információkkal szolgálhat.

Azt is lényegesnek tartjuk hangsúlyozni, hogy a hálózatelemzés szakirodalomgyújtés során történô felhasználása semmiképpen sem helyettesít olyan módszereket, mint pl. a metaanalízis, hiszen teljesen más logikát követ. Jóllehet - hasonlóan a hálózatelemzéshez - a metaanalízis esetében is az összefüggések feltárásának célját hangsúlyozzák egyes szerzók (pl. Szokolszky, 2004). Lényeges különbség azonban, hogy amíg a metaanalízis során a tartalom kiemelt jelentôséggel bír - hiszen e módszer az összefüggéseket a kutatási eredmények összesítésén keresztül tárja fel -, addig a 
hálózatelemzés a felszínen marad, nem mélyed el a részletekben. Glass (1976) szerint a metaanalízis egyedi vizsgálatok eredményein végzett statisztikai elemzés, a megállapítások integrálása céljából. Vagyis itt maga a tartalom az, ami fókuszba kerül. Ezzel szemben Csermely (2020) a szociális hálózatok példáján keresztül hívja fel a figyelmet arra a hatalmas információvesztésre, amely a hálózatkutatás inherens része. Eszerint amikor definiáljuk, hogy mik a hálózat elemei (ún. nódusai vagy csomópontjai), az elemek identitásáról („tartalmáról”) elfeledkezünk. Vagyis, ha az ismerôsi körünkből rajzolunk fel egy társas kapcsolati hálózatot, akkor mindegyikükrôl egyformán, mint emberrôl kell beszélnünk, figyelmen kívül hagyva az egyéni jellegzetességeket (pl. kor, nem, belsô értékek, személyiségjegyek stb.). Ez pedig egy jelentôs, ám szükséges információszegényítés, melyet Csermely a munkamemóriánk korlátozott kapacitásával indokol. Ám ugyanez igaz bármely más hálózatra, így a szakirodalmak hálózatára is. Természetesen kiragadhatjuk és tanulmányozhatjuk a hálózat egy-egy nódusát, ám a teljes hálózat szintjén csak publikációk kategóriáiról beszélhetünk. Ez egy markáns eltérés a metaanalízishez képest. Egyúttal azt is eloorevetíti, hogy teljesen más a két módszer kimenete. Amíg a metaanalízis egy adott témán belüli összefüggéseket tárja fel a részletek szintjén, addig a hálózatelemzés segítségével elsôsorban témák (szakirodalom-csoportosulások) között fedezhetünk fel kapcsolatokat.

Egy másik nézôpontból is megközelíthetjük a hálózatelemzés szakirodalmi áttekintés folyamatában való szerepét. Ez pedig a mintavételezés. Mayer-Schönberger és Cukier (2014) hangsúlyozzák, hogy a technológiai fejlődésnek köszönhetôen egyre inkább az a cél, hogy egy teljes sokaságot tanulmányozzunk. Úgy fogalmaznak, hogy „a big data korszakában a véletlen mintavételhez folyamodni olyan, mint lovaglóostort ragadni egy motorizált világban" (Mayer-Schönberger és Cukier, 2014, 41). Mindemellett azonban a szakirodalom-gyújtés maga valójában egy mintavételezés: egy adott témában releváns tudományos kutatásokból való merítés. Belátható, hogy minél tágabb a szóban forgó téma, annál kevésbé lehet reális a teljes körú lefedettség iránti igény. Ilyen értelemben a „lovaglóostor” továbbra is nélkülözhetetlen kellék, azonban a hálózatelemzés módszere segíthet abban, hogy az „ugratópálya kevesebb akadállyal túzdelt legyen”.

\section{A HÁLÓZATELEMZÉS ELMÉLETI ALAPJAI}

Az irodalomkutatás során - a nyomtatott formátumú irodalmak mellett - a szakirodalmi adatbázisok használata egy kutatótól sem idegen. Hagyományosan ezeken az online felületeken lehetôség van arra, hogy különbözô szempontok mentén futtassunk kereséseket, pl. szerzô, kulcsszó, folyóirat, dátum stb. Másképpen fogalmazva az ilyen adatbázisok komplex rendszerében különbözô kategóriaképzô változók segítenek nekünk eligazodni. Ahhoz ugyanis, hogy az ilyen adatbázisok esetében komplex rendszerekkel van dolgunk, kétség sem fér. A ScienceDirecten például csak az ingyenesen hozzáférhetố (open access) tudományos cikkek száma meghaladja az 1,2 milliót, a Taylor \& Francis Online weboldalán pedig több mint 4,5 millió publikáció érhetô el. Bár ezek a számok is igen meggyôzőek, a tudományos élet közösségi hálójának számító ResearchGate nem kevesebbet állít, mintsem, hogy 135 millió publikációs oldalhoz biztosít hozzáférést. 
Ahogy Barabási (2016, 39) fogalmaz: „[M]inden komplex rendszer mögött egy bonyolult hálózat áll, s az határozza meg az adott rendszer elemei közötti kölcsönhatásokat." A könyvfejezet címe, melyben Barabási a fentieket írja, úgyszintén a komplex rendszerek és a hálózatok szoros kapcsolatát vetíti eloore: „Hálózatok mutatják meg a komplex rendszerek lényegét” címú fejezet. Hangsúlyozza továbbá, hogy a rendszer megértéséhez meg kell ismernünk annak „kapcsolási rajzát” (a gráfot), ezt pedig a hálózatelemzés módszertana teszi lehetôvé. Ezzel egybehangzó módon Caldarelli (2020) úgy fogalmaz, hogy a gráfok jó megoldást kínálnak a komplex rendszerek leírására. Úgy véljük, hogy ezek alapján ígéretes és indokolt elindulni egy olyan úton, melynek során a hálózatelemzést használjuk fel egy adott témakör megismerésére. Felmerülhet a kérdés, hogy vajon mennyire rögös ez az út, avagy ez a módszer mennyire követel meg egy olyan mértékú matematikai elóképzettséget, amely jelentôsen túlmutat a pszichológiai képzések keretében szerezhetô tudásanyagon. Hiszen talán még bô harmincöt év távlatából is él az a közfelfogás, miszerint a pszichológia a matematikával nehézkesen rokonítható „nagyobbrészt spekulatív jellegú tudomány”, noha Vargha (1984) egy teljes tanulmányt szentelt ennek cáfolatára. Sebestyén (2011) szerint a hálózati kapcsolatok és struktúrák elemzése némiképp szerényebb matematikai háttérre épít, és a gráfelmélet egyszerúbb eredményeit integrálja. Barabási (2016) pedig megállapítja, hogy bár a hálózatkutatás számos fogalma valóban a gráfelméletbôl ered, utóbbitól az különbözteti meg, hogy a hálózatkutatás tapasztalati alapú, és az adatokat meg az eredmények felhasználhatóságát állítja a középpontba. Mindemellett ma már a gyakorlati kivitelezést nagyban könnyítik bizonyos szoftverek (pl. Gephi, NodeXL, GraphStream, Pajek stb.), illetve különbözó programnyelvekbe hívható csomagok (pl. az R-ben az igraph vagy a Pythonban a NetworkX). Ezek az eszközök jelentôs terhet le tudnak venni a kutató válláról.

Célunk az, hogy bemutassuk a hálózatelemzés alkalmazhatóságát, illetve a gyakorlati kivitelezés során hasznos eszközöket egy esettanulmányon keresztül. A továbbiakban áttekintünk néhány hálózatelméleti fogalmat. Teljeskörüségre az alapfogalmak terén sem törekszünk, csupán azokat ismertetjük, amelyek esettanulmányunkban megjelennek, így annak megértését szolgálják.

- Csomópontok, csúcsok: A hálózat alkotóelemeit csomópontoknak hívjuk a hálózatkutatásban, a gráfelméletben csúcsnak. A csomópontok számát $N$-nel jelöljük, az egyes pontokat pedig $i=1,2, . ., N$ sorszámmal különböztetjük meg egymástól (Barabási, 2016). Gyakran találkozhatunk a nódus kifejezéssel is. A nódus definiálása a hálózat definíciójának elsố eleme (Csermely, 2005, 2020), vagyis elsôként mindig azt kell meghatározni, hogy kiket vagy miket reprezentálnak a hálózat csomópontjai. Egy adott témához köthetô szakirodalmak hálózatában a csomópontok maguk a szakirodalmak.

- Kapcsolatok, élek: A csomópontok közötti kapcsolatokat (a hálózat vonalait vagy nyilait) a hálózatkutatásban hagyományosan kapcsolatoknak hívjuk, a gráfelméletben pedig éleknek. A kapcsolatok számát L-lel jelöljük, ez tehát a csomópontok közötti kapcsolatok teljes száma (Barabási, 2016). A hálózatok definíciójának második eleme annak meghatározása, hogy mik legyenek ezek a kapcsolatok (Csermely, 2005, 2020). Egy szakirodalom-hálózatban a kapcsolat már nem anynyira egyértelmú, mint a csomópont, mivel több logika mentén is kapcsolatba 
hozható két szakirodalom. Két csomópont közé él húzható például, ha megegyezik a szerző, ha egyik publikáció hivatkozik a másikra, ha mindkettônél megjelenik ugyanaz a kulcsszó stb.

- Irányított és irányítatlan hálózatok: Maga a hálózat lehet irányított vagy irányítatlan. Elóbbiról akkor beszélhetünk, ha az éleknek iránya van, vagyis az egyik csomópont egyértelmúen rámutat egy másikra, utóbbi azonban nem feltétlenül viszonozza ezt a kapcsolatot (pl. rokonszenvi kapcsolatok egy munkahelyi közösségben). Irányítatlan hálózat esetében nincs értelme az élek irányáról beszélni, mivel a kapcsolatok eleve kölcsönösnek tekinthetôk. Ilyen hálózatot alkotnak például a tudományos együttmúködések (Barabási, 2016).

- Fokszám: A hálózat csomópontjainak talán legfontosabb tulajdonsága a fokszáma, ami egy adott csúcs és a hálózat többi csúcsa közötti kapcsolatok száma. Az $i$-edik pont fokszámát $k_{i}$-vel jelöljük a hálózatban. Amennyiben egy hálózat irányított, úgy elkülöníthetünk bemeneti és kimeneti fokszámokat. Elôbbiek a beérkezô, utóbbiak pedig a kifutó élekre utalnak, ezek összegeként pedig megkapjuk egy csomópont fokszámát. Irányítatlan hálózatban azonban nincs értelme be- és ki fokszámokról beszélni (Barabási, 2016).

- Utak és távolságok: A hálózat csúcsainak távolságát a hálózatelemzésben a köztük lévô út hosszával operacionalizáljuk. Az út azon - egymástól különbözô - csomópontokból áll, melyeket a köztük lévô élek kötnek össze, így maga az út hossza az utat alkotó kapcsolatok száma. A hálózat két tetszóleges csúcsa ( $i$ és $j$ ) között a legrövidebb út az, amely a legkevesebb pontot tartalmazza (ezt hagyományosan $d_{i j}$-vel, vagy egyszerúen $d$-vel jelöljük). Két csomópont között több ilyen $d_{i j}$ hoszszúságú út is lehet. Irányítatlan hálózatokban az $i$-edik és a j-edik pont távolsága megegyezik a jedik és az $i$-edik pont távolságával, tehát $d_{i j}=d_{j i}$ (Barabási, 2016).

- Közösségek: A hálózatkutatásban a közösségek (csoportok) úgy írhatók le, mint a csomópontok sûrú csoportosulásai, melyek szorosan kapcsolódnak egymáshoz, és lazán kapcsolódnak a hálózat többi csúcsához (Khan és Niazi, 2017).

- Modularitás: A modularitás lényegében egy adott közösségfelosztás „jóságát” mérô mutatószám. Azt vizsgálja, hogy az adott közösségen belül mennyivel van több kapcsolat, mint amennyi véletlenül is várható lenne egy hasonló karakterisztikákkal rendelkezô (ld. csúcsok és élek száma) hálózat esetében (Bene, 2016). Akkor a legjobb a közösségek elkülöníthetôsége, ha a modularitás maximális értéket mutat.

Bár számos alapfogalom nem került bemutatásra (pl. centralitásmutatók), jelen publikációban ezek nem kerülnek elô. Ahogyan arra korábban utalást tettünk, jelen írásunkban egy esettanulmányon keresztül szemléltetjük a hálózatelemzés irodalomkutatás területén való felhasználását. Az esettanulmányunkban választott szakmai terület, amelyet a hálózatelemzés segítségével vizsgálunk, a pszichológiai tanácsadás, pontosabban az ehhez a területhez kapcsolható szakirodalmak. 


\section{A PSZICHOLÓGIAI TANÁCSADÁS}

A pszichológiai tanácsadás egy igencsak összetett terület, és mint ilyen a gyakorlati munkát megkönnyítendő, illetve a szakterületek munkáját bemutató és rendszerbe helyezó útmutatók rendkívül hasznosak, már-már nélkülözhetetlenek. Éppen ezért a nemrégiben elkészült szakmai alapprotokoll (Kissné Viszket és Mogyorósy, 2019) egy mérföldkô, illetve egy fontos irányadó dokumentum a szakma múvelôi számára. Ebben az alapprotokollban a szerzók igazolják a szakterület gyakorlati komplexitását. Egyfelôl bemutatják, hogy a tanácsadás hol jelenik meg, egyben három fố területre osztják fel a hazai foglalkoztatási rendszert: köz- és civil szféra; szervezetfejlesztés és pszichológiai tanácsadás vállalkozóként. Másfelôl aszerint írják le a pszichológiai tanácsadást, hogy az milyen problématerületekre kíván választ adni, miben akar segítséget nyújtani. Ez lényegében arról szól, hogy mi a tanácsadás fókusza, amely a szakterület több szerzô (pl. Buda, 2009; Szemán és Karner, 2017) által hangsúlyozott sajátossága. Ilyen fókuszok például a kapcsolati nehézségek, tanulási és készségdeficitek, stresszkezelés, személyes/társas alkalmazkodási nehézségek stb. Végül az alapprotokoll felvonultatja azon tevékenységeket, fókuszált intervenciókat, melyek úgymond reflektálnak a részletezett problématerületekre. A pszichológiai tanácsadás komplexitása azonban nem csupán gyakorlati, de elméleti szempontból is igazolható. Már az 1980-as évek elején is több mint 200 megközelítési módra utal a szakirodalom (pl. Herink, 1980; Corsini, 1981). A tanácsadó szakemberek tehát az elméletek és módszerek széles skálájából válogathatnak, ezek pedig nem feltétlenül kizárólagosak, hanem keverednek a tanácsadó eszközrepertoárjában. Fonyó és Pajor (2000) arról számolnak be, hogy számos hivatásos konzultáns az elméletek és módszerek alkalmazását tekintve eklektikusnak mondható. Azon szakemberek, akik ezt a megközelítést alkalmazzák, más és más módszereket használnak a különféle klienseik szükségleteinek kielégítésére. Vagyis az összetettség nem csupán a szakterület, hanem a gyakorló szakember szintjén is megvalósulhat. Ezzel szinkronban van Bagdy (2009) gondolata is, amelyben egyértelmúen rendszerként definiálja a szakterületet. Eszerint a „nem terápiás” pszichológiai módszerek (ennek megfelelốen a pszichológiai tanácsadás is) gyakran több forrásból táplálkoznak, és eklektikus rendszert alkotnak. A fentiek alapján úgy véljük, hogy amennyiben az elemzésünk fókuszát a pszichológiai tanácsadáshoz kapcsolódó publikációkra helyezzük, úgy a komplex rendszer jelleg nem csupán a szakirodalmi adatbázisok összetettsége és bonyolult szervezôdése miatt igazolható, hanem maga a szakterület is egy ilyen összetett rendszert alkot. Úgy is mondhatjuk, hogy valójában a pszichológiai tanácsadás komplex rendszerét az ehhez kapcsolódó szakirodalmak komplex rendszerével operacionalizáljuk, és a hálózatelemzés eszközével vizsgáljuk.

\section{MÓDSZER}

Jelen írásunkban azt tûztük ki célul, hogy a hálózatelemzés hasznosíthatóságát bemutassuk - egy esettanulmányon keresztül - az irodalomkutatás területén. Ennek megfelelően maga a hálózatelemzés adja a módszertani rész gerincét. Ezzel együtt azonban egy másik fontos módszertani megoldásról is szót kell ejtenünk, egy olyan eszközrôl, 
amely az adatgyújtéshez kapcsolódik. Hiszen a hálózatelemzés azon a ponton tudja kezdetét venni, amikor rendelkezésünkre állnak a számunkra szükséges adatok, mégpedig abban a struktúrában, amelyet az elemzés megkövetel. A hálózatelemzés tehát csupán az adatok feldolgozásánál kerül elô. Ez utóbbi folyamat során alkalmazott elemzési logikát is jelen pontban ismertetjük.

\section{Mintaválasztás}

A mintaválasztás során két fố kérdés merül fel. Az elsô kérdés, hogy honnan, milyen forrásból - tudományos adatbázisból - történjen meg az adatgyújtés. Választásunk a ResearchGate oldalra esett. A 2008 óta múködô oldalt informális módon a tudományos világ Facebookjának is szokták hívni, mivel megváltoztatta a tudósok egymással való kommunikációját (Berta, 2012). A ResearchGate jól áttekinthetô, online rendszere a szerzóknek, illetve a publikációknak. Emellett azonban egy másik érv is az oldal mellett szólt, mégpedig az, hogy annak felépítése szinkronban volt azzal a kapcsolódási logikával, amelyet a majdani hálózat kirajzolására elgondoltunk. Emlékeztetôként a hálózat definiálásának második lépése az élek definiálása, vagyis annak meghatározása, hogy mit is értünk kapcsolat alatt. Mi egy olyan hálózatot akartunk megrajzolni, amelyben a hasonló szakirodalmak kapcsolódnak egymáshoz (vagy legalábbis közel helyezkednek el), míg a különbözók egymástól távol vannak. A ResearchGate egy olyan ajánlórendszert múködtet, mely valamennyi publikációnál megjelenít ajánlott irodalmakat.

Általában véve az ajánlórendszerek az e-kereskedelem területén elterjedt megoldások, melyek hasznosnak bizonyultak mind szolgáltatói, mind pedig fogyasztói oldalon. Ami a szolgáltatói oldalt illeti, az ajánlórendszerek több termék értékesítéséhez vezetnek, vagyis bevételnövelô hatásuk van. Fogyasztói oldalról pedig egyszerúsítik azt a folyamatot, hogy a felhasználók a keresett termékre találjanak, döntést hozzanak, illetve valamilyen új, számukra érdekes termékre leljenek (Pu, Chen és Hu, 2011). Bár a tudományos adatbázisok nem nevezhetôk egy klasszikus e-kereskedelmi platformnak (még akkor sem, ha bizonyos tartalmak elérése fizetési kötelezettséggel jár), az alkalmazott ajánlórendszerek szerepe és múködése nagyban hasonlít azokhoz, amikkel akár egy webshopban is találkozhatunk. Ami az ajánlórendszerek múködési logikáját illeti, három típust különíthetünk el (Isinkaye, Folajimi és Ojokoh, 2015). A leginkább elterjedt kollaboratív szúrésnél a rendszer hasonló preferenciájú felhasználókat azonosít, és az ô viselkedésükre (pl. felhasználói értékelés) alapozza az ajánlott tartalmakat. A tartalomalapú szúrés ezzel szemben az adott felhasználó viselkedési elôzményeire építi a predikciót, figyelmen kívül hagyva az egyéb felhasználókkal kapcsolatos információt. Léteznek továbbá a hibrid megoldások, melyek valamilyen módon a két szúrési típust ötvözik. Az, hogy a ResearchGate egészen konkrétan milyen megoldást használ a kapcsolódó tartalmak megjelenítésére, nem ismert, ahogy az sem, hogy az algoritmusban milyen súllyal szerepelnek az egyes publikációkhoz köthetô lényeges információk (pl. hivatkozások száma, idézettség stb.). A fentiek okán az ajánlórendszer múködési logikájától elvonatkoztatunk - azt adottságként kezeljük -, és arra fókuszálunk, ami a használt szûrési metodikától független. Vagyis arra, hogy minden cikk leg- 
alább egy másik cikkre mutat rá, ami a hálózatelemzés fogalmait használva annyit tesz, hogy minden cikk egy csomópont vagy csúcs, amelyból legalább egy él fut ki. Ha pedig ilyen kapcsolatot csokorba gyújtünk, akkor elvárható, hogy ezek a kapcsolódások nem izolált formákat alkotnak, hanem egy egységes rendszerbe, gráfba szervezôdnek.

A második kérdés az, hogy milyen tartalmak gyújtése valósuljon meg. Ez elsô megközelítésre egyértelmúnek tûnik. Mivel egy szakirodalmi hálózatot akarunk megrajzolni, így evidens, hogy a nódusokat a szakirodalmak (publikációk és könyvfejezetek) jelentik. Technikai szempontból azonban tisztázandó, hogy ez mit is takar, vagyis pontosan mi az, ami egy-egy csomópontot azonosít - egyben garantálja annak egyediségét. Nem optimális megoldás, ha csak a publikáció címével azonosítjuk a nódust, hiszen a címek ismétlốdhetnek. Éppen ezért mi azt a megoldást választottuk, hogy a szakirodalmakhoz tartozó linkeket gyújtjük le. Ez ugyanis egészen biztosan egyedi változó: egy publikációhoz garantáltan egyetlen link tartozik. A tartalmat érintô kérdéshez kapcsolódik az is, hogy milyen publikációkhoz tartozó linkek gyújtése történjen meg. Öszszeállításra került részünkrôl egy - 74 elemú - lista, amely a pszichológiai tanácsadás témaköréhez kapcsolódó releváns kulcsszavakat és kifejezéseket tartalmazza. Ezen a ponton felmerülhet a kérdés, hogy mi van abban az esetben, ha a kulcskifejezések listája nem teljes körü (kihagytunk egy-egy fontos kifejezést). Azt gondoljuk, hogy maga a hálózatelemzés módszere ezt a helyzetet is némiképp áthidalja, hiszen a hálózatban az egyes cikkekhez kötôdô (ajánlott) publikációk révén kiemelkedhetnek olyan új területek, melyekre eredetileg nem volt a listában kifejezés.

\section{Automatizált adatgyújtés: web-scraping}

Miután eldöntöttük, hogy honnan és milyen adattartalmakat gyújtsünk ki, a megvalósítás technikáját kell mérlegelnünk. A kérdés ebben az esetben az, hogy miként történjen meg az adatgyújtés, illetve milyen struktúrában tároljuk a megszerzett adatokat. A kulcsszavakra kapott találatok kézi legyújtése meglehetôsen hosszadalmas és monoton folyamat. Továbbá azzal is számolni kell, hogy a több ezer találathoz tartozó link legyüjtése csupán a folyamat elsô lépése, hiszen csak ezt követôen jön a kapcsolódó (ajánlott) publikációkhoz tartozó linkek megszerzése. Ez utóbbi nagy variabilitást mutat. Vannak publikációk, melyekhez csupán egyetlen ajánlott szakirodalom van nevesítve, de bizonyos esetekben több mint tíz kapcsolódó publikációval találkozhatunk. Ez pedig újabb, sok ezer adat kigyújtését vetíti előre. Az adatvolumen ekkora nagysága azt sugallja, hogy az adatgyújtés csupán automatizált módon vállalható reális keretek között. Az automatizált adatgyújtés kapcsán ki kell térnünk a web-scraping fogalmára. A web-scraping lényegében a manuális adatgyújtést próbálja reprodukálni, és segítségével webes felületekrôl, strukturált formába rendezve nyerhetôk adatok egy speciális szoftverrel (Giczi és Szóke, 2017). Az adatgyújtés során mi is a web-scraping módszerét használtuk, egy Python 3.0 programnyelven megírt programkód segítségével. A Python egy dinamikus, bôvíthetô, viszonylag egyszerú szintaxisú programnyelv, melyet 1989 óta fejlesztenek (Swinnen, 2005). Magának a nyelvnek a módosulásán kívül a fejlesztések körébe tartoznak a különbözó programcsomagok, melyek egy-egy specifikus területet céloznak meg. A web-scraping esetében ilyen csomag az általam 
is használt Beautiful Soup (továbbiakban: BS). A hivatalos dokumentáció alapján (Richardson, 2019) a BS egy olyan Python könyvtár, amely HTML és XML fájlokból nyer ki adatokat. Ilyen módon a ResearchGate weboldalára is alkalmazható volt.

Az adatgyüjtéshez kapcsolódó, soron következô kérdés, hogy milyen struktúrában valósuljon meg az automatizált módon legyújtött adatok tárolása. Az adatokat nyilvánvalóan olyan struktúrában kell tárolni, hogy azok a hálózatelemzés megfelelô inputjai legyenek. Az egyik lehetôség az, hogy az adatokat ún. szomszédsági mátrix formájában tároljuk - ennek annyi sora és oszlopa van, ahány nódus szerepel a hálózatban. Ennél azonban praktikusabb megoldásnak gondoltuk, ha csupán egy két oszlopból álló adattáblával dolgozunk, a sorokban pedig az éleket rögzítjük, az elsô oszlopban a forrást (amelyik linken az ajánlott publikációk fel vannak sorolva), a másodikban pedig a célt (az ajánlott publikációkhoz tartozó linket).

\section{Adatok feldolgozása}

Az adatok feldolgozása a hálózatelemzés módszerével történt. Ennek megkezdése elốtt azonban el kellett döntenünk, hogy milyen típusú hálózatot rajzoljunk ki: irányított vagy irányítatlan hálózattal dolgozzunk. Ami miatt ez a kérdés felmerült, hogy a ResearchGate ajánlórendszere alapvetően az irányított hálózat felrajzolását kínálná. Az egyes szakirodalmaknál megnevezett ajánlott irodalmak esetében nem feltétlenül igaz, hogy azok a publikációk úgymond „viszonozzák a jelölést”, vagyis visszamutatnak a forrásra. Amennyiben vállalásunk az lett volna, hogy bemutassuk a ResearchGate ajánlórendszerének azon szeletét, amely a pszichológiai tanácsadásról szól, úgy nem is kérdés, hogy maradni kellett volna az irányított hálózatnál. Azonban nem ez volt a célkitûzés, hanem a pszichológiai tanácsadásban jelenleg releváns publikációk kapcsolatrendszerének felrajzolása, melyben a ResearchGate egy alkalmas platform, és annak ajánlórendszere az adatgyújtés eszköze, nem pedig a célja. Ezért az ajánlórendszer logikája helyett inkább ahhoz a meglátáshoz tartottuk magunkat, hogy egy publikációnál ajánlott szakirodalmak elvben azért vannak szerepeltetve, mivel tematikai átfedés van közöttük, osztoznak egy adott témán. Ez pedig már egy kölcsönös kapcsolatot feltételez, amely az irányítatlan hálózat alkalmazása felé mozdítja el a módszertant.

Az irányítatlan hálózatot a Gephi (Bastian, Heymann és Jacomy, 2009) nevú szoftverben rajzoltuk meg. E szoftver mellett szólt az, hogy egyrészt nagy adatvolument képes kezelni, másrészt több beépített algoritmussal rendelkezik. Ilyen algoritmus a közösségdetekcióra használt modularitásalapú klasszifikáció. A modularitásról - a közösségfelosztás ,jóságát” mérô mutatószámról - az alapfogalmak ismertetésénél már szót ejtettünk. Azonban nem csak az előre meghatározott közösségfelosztások ,jósága" mérhetô, hanem léteznek modularizációoptimalizáló algoritmusok is, amelyek célja az, hogy megtalálják a legnagyobb modularitásértéket adó közösségfelosztást (Bene, 2016). Ilyen algoritmust használ a Gephi is (Blondel, Guillaume, Lambiotte és Lefebvre, 2008), melynek révén azt a felosztást kapjuk meg, amelyik a legnagyobb modularitásértékkel rendelkezik. Megjegyzendô, hogy több ilyen algoritmus is létezik, de mindegyik végcélja a hálózat csúcsainak csoportosítása a köztük lévô kapcsolatok erôssége alapján. Az erôsen kapcsolt nódusok valószínúleg egy közös fürtbe kerülnek, füg- 
getlenül attól, hogy éppen melyik algoritmusra esik a választásunk (Cherven, 2015). Tehát ami az ily módon detektált közösségek értelmezését illeti, azt mondhatjuk, hogy az egyes közösségekben található csúcsok jobban összetartoznak, mint a közösségek közötti csúcsok. A közösségdetekciós eljárást elsô körben, mint adatpurifikációs eszközt használtuk. Ennek során megváltunk azoktól a nódusoktól és élektôl, amelyek leszakadva, izolált csoportokban voltak jelen a hálózatban. A szakirodalmak hálózata egy további adatredukciót követôen érte el végsô formáját. Ez utóbbi során azon nódusokat vettük ki a hálózatból, melyek csupán egyetlen kapcsolattal rendelkeznek. Megfigyelhetô volt ugyanis, hogy több ernyôszerú alakzat is található a hálózatban. Ezeknél egy csúcsból több él is kifut, és egyetlen, „záró” csúcsban végzôdik, ahonnan nem fut ki további él. A gyakorlatban ez azt jelenti, hogy számos olyan publikáció szerepel a hálózatban, melyek fokszáma csupán a náluk feltüntetett ajánlott szakirodalmak miatt magas, nem pedig azért, mert ók maguk olyan sokszor jelentek meg ajánlott szakirodalomként a többi publikációnál. Ez egy komoly torzítást jelent, amely miatt bizonyos publikációk indokolatlanul emelkednek ki releváns (magas fokszámú) csomópontként a hálózatban.

\section{A hálózatstruktúrák tartalomelemzése}

A szakirodalmak hálózatának vizsgálata során két fơ kérdés foglalkoztatott bennünket. Egyrészt, hogy milyen fô témakör-csoportosulások azonosíthatók a gráfban, másrészt pedig, hogy ezek egymáshoz képest hogyan helyezkednek el. Így elsôként a - fenti lépések elvégzését követôen kapott - hálózaton egy újabb automatizált közösségdetekciót futtattunk, ezúttal már nem adatpurifikáció céljából. A kapott közösségeket ezután egyenként megvizsgáltuk, és elneveztük ôket. Ennek során elôször szógyakoriság-elemzést végeztünk a publikációk címeire, majd megvizsgáltuk, hogy az egyes közösségeket milyen - tematikai szempontból összetartozó - kulcsszó-kombinációkkal tudjuk a legjobban lefedni. A lefedettség mértékét egy arányszámban fejeztük ki, és abban az esetben tekintettünk egy közösséget értelmezhetônek, amennyiben az elérte a 60\%-ot. Az így megmaradt szakirodalom-közösségeket egyenként megvizsgáltuk. A jellemzésnél kitüntetett figyelmet szenteltünk azon publikációknak, melyek magas fokszámmal rendelkeztek az adott közösségben - ily módon annak kiemelkedô fontosságú csomópontjainak tekinthetôk.

Az elnevezett közösségek egymáshoz való kapcsolatának erôsségét egymáshoz vezetô úthosszok segítségével operacionalizáltuk. A távolságkalkulációhoz elôször valamennyi közösségbool kiválasztásra került a - fokszám alapján - leginkább kiemelkedô szakirodalom, majd kiszámoltuk, hogy ezek hány lépés távolságra helyezkednek el a hálózat valamennyi csomópontjától. Ezt követôen megnéztük, hogy a korábban detektált közösségeknél mekkora ezen távolságok átlaga. Mivel az egyes közösségeket egyetlen prototipikusnak tekintett szakirodalom képviselte, így ebból az következik, hogy egy tetszóleges $A$ közösség $B$ közösségtôl vett távolsága nem egyezik meg $B$ közösség $A$-tól való távolságával. Ezért a végsố távolságokat az egyes közösségpárok egymáshoz vezetô úthosszainak átlagolásával kaptuk meg. Ezt a lépést egy újabb, egyszerúsített, ezúttal irányított hálózat megrajzolása követte, amelyben a nódusok a 
témakörök voltak, és amelyben kizárólag a legközelebbi témakörrel való kapcsolatok voltak feltüntetve.

\section{EREDMÉNYEK}

Ebben a pontban ismertetjük azokat az eredményeket, melyeket a fent bemutatott módszertani lépések során kaptunk. Megjegyzendô azonban, hogy egyes lépések nehézkesen szétválaszthatók az eredményektól, így bizonyos módszertani elemek is viszszaköszönnek. Vagyis jelen fejezet részben az előző folytatásának, kibontásának fogható fel.

A ResearchGate oldalon végzett automatizált adatgyújtés során egy olyan hálózatot kaptunk, melyben $\mathrm{N}=61026$ nódus (szakirodalom link) szerepelt. A hálózat éleinek száma L = 70821 volt. A kétlépéses adatpurifikációt követően azonban ez a gráf jelentôs mértékben megritkult, hiszen kizártuk azokat a csomópontokat és éleket, amelyek izolált, leszakadó csoportokat képeztek a hálózatban. A végleges hálózat csomópontjainak száma $\mathrm{N}=10311$, a kapcsolatok száma pedig L = 20377 lett. Ennek a hálózatnak a nódusaira futtattuk le azt az algoritmust, melynek célja tematikai szempontból jól azonosítható, különálló közösségek feltárása volt. A kapott 95 közösség elemszámai nagy variabilitást mutattak. A több száz szakirodalmat magukban foglaló közösségek mellett voltak egészen kis csoportosulások is, melyek elemszáma nem érte el a 10-et. Ez utóbbiaktól megválva 39 közösség maradt. Ezekre végeztük el a fent részletezett szógyakoriság-elemzést, majd az értelmezést. A kulcsszó-kombinációk segítségével 26 közösségnek sikerült jelentést (elnevezést) adni. Ezekben együttesen 7549 szakirodalom szerepelt, vagyis ezzel a lépéssel ismételten csökkent a hálózat nódusainak száma. Nem csupán az volt releváns kérdés, hogy tartalmi szempontból mit mondhatunk ezekről a közösségekrôl (vagyis milyen elnevezést adhatunk nekik), hanem az is, hogy ezek miként helyezkednek el egymáshoz képest. Az ismertetést ez utóbbival kezdjük, a közösségek tartalmi bemutatását ezt követôen szerepeltetjük.

Ahogyan az elôzó pontban írtuk, a közösségek egymással való kapcsolatának elemzése során a távolságokból (úthosszakból) indultunk ki. Feltételezhetô ugyanis, hogy azon közösségek, melyek egymáshoz közel helyezkednek el, jobban összetartoznak, mint az egymástól távol esố közösségek. Amennyiben nódusok szintjén vizsgálódunk, a távolságmetrika viszonylag kézenfekvô, hiszen azt kell megnézni, hogy egy tetszôlegesen kiválasztott nódustól hány lépést kell megtennünk, hogy egy másik nódushoz eljussunk. Irányítatlan hálózatban ráadásul ez a távolság ekvivalens azzal, ha az utóbbi csúcsból lépegetünk az elôbbibe. A közösségek távolságának meghatározásánál azonban már nem ennyire egyértelmú a távolságok kalkulációja. Egy lehetséges megoldás, hogy elsô lépésként kiszámítjuk minden nóduspár egymástól vett távolságát, majd ezen lépésszámok átlagolásával határozzuk meg az egyes közösségek távolságát. E meglehetôsen számításigényes módszer helyett egy olyan megoldást választottunk, mellyel lényegében egy becslést teszünk a közösségtávolságokra.

Ennek elsố lépéseként valamennyi közösségbôl célzottan kiválasztottunk egyetlen publikációt. Célunk az volt, hogy e szakirodalmak jól képviseljék az adott közösséget, másképp fogalmazva legyenek egyfajta prototipikus tagjai a közösségnek. A szelekció 
a fokszám alapján történt, ugyanis ez megmutatja, hogy mely szakirodalom rendelkezik a legtöbb kapcsolattal. Előfordult olyan közösség is, amelyben több publikáció is az elsố helyen állt a fokszám szerinti rangsorban. Ebben az esetben azt a publikációt részesítettük előnyben, amelyet több alkalommal hivatkoztak (a ResearchGate alapján). A második lépésben - egy erre írt programkód segítségével - kiszámítottuk a 26 prototipikus szakirodalom valamennyi (7548) nódustól vett távolságát, így a saját közösség csúcsaitól vett távolságokat is. Ezt követốn a kiválasztott nódusok és az egyes közösségek nódusaihoz vezetố úthosszok átlagolásával becsültük meg a közösségek egymástól való távolságát. A végsố távolságbecsléseket úgy kaptuk meg, hogy az összetartozó távolságokat átlagoltuk. Tetszôleges $A$ és $B$ közösség távolságát tehát a következóképpen kapjuk meg:

- Kiszámítjuk az A közösségból kiválasztott szakirodalom valamennyi B közösségbe tartozó nódustól vett távolságát, majd ezeket az úthosszokat átlagoljuk.

- Kiszámítjuk a B közösségból kiválasztott szakirodalom valamennyi A közösségbe tartozó nódustól vett távolságát, majd ezeket az úthosszokat átlagoljuk.

- A fent megkapott átlagoknak kiszámítjuk a számtani közepét (átlagát).

A fenti módszer segítségével állapítottuk meg azt, hogy mely közösségek tartoznak öszsze leginkább. Hiszen valamennyi közösségnél megkaptuk a többi közösségtôl való távolságok rangsorát. Ezt a rangsort felhasználva rajzoltuk meg a közösségek hálózatát, amely - ellentétben a szakirodalmak hálózatával - egy irányított és súlyozott hálózat (1. ábra). Ebben a hálózatban minden közösségtôl a hozzá legközelebb esô közösség irányába fut ki egy él. Az élek vastagsága a távolság függvényében alakul (a közelebbi kapcsolatot vastagabb él reprezentálja), vagyis az élek súlya a távolságkülönbségek lineáris transzformációval képzett mutatója. A nódusok mérete a közösségek elemszámával arányos.

Az ábrán jól látható, hogy a korábban azonosított közösségek négy fragmentumba csoportosulnak, továbbá valamennyi fragmentumban vannak központibb nódusok, melyek több közösséggel is kapcsolatban vannak. Szembetúnô az is, hogy ezek a központibb nódusok többnyire nagyobb elemszámú közösségeket takarnak, a kisebb közösségek (pl. könyvajánlók) jellemzóbben vesznek fel periférikusabb helyet.

\section{Az eredmények megvitatása}

Jelen publikációban arra vállalkoztunk, hogy egy esettanulmányon, pszichológiai tanácsadás témakörén keresztül mutassuk be a hálózatelemzés módszerének használhatóságát a szakirodalmi tájékozódás során. A ResearchGate adatbázisát felhasználva - egy web-scraping adatgyújtést követôen - az adatok célirányos redukciójával végül egy 10311 elemú (csomópontú) hálózat megalkotása, majd elemzése valósult meg. Ez utóbbi részeként témaköröket (a hálózatkutatás kifejezésével éve: közösségeket) is sikerült azonosítani a megrajzolt gráfban. Ebben a hálózatban összesen 39 közösséget detektáltunk, melyek közül 26-hoz tudtunk témakört rendelni, és egyben elnevezni. A kapott témaköröket illetôen voltak egészen újak is, melyekre eredetileg irányult célzott keresés és adatgyújtés. Megvizsgáltuk a közösségek egymással való kapcsolatát, és 


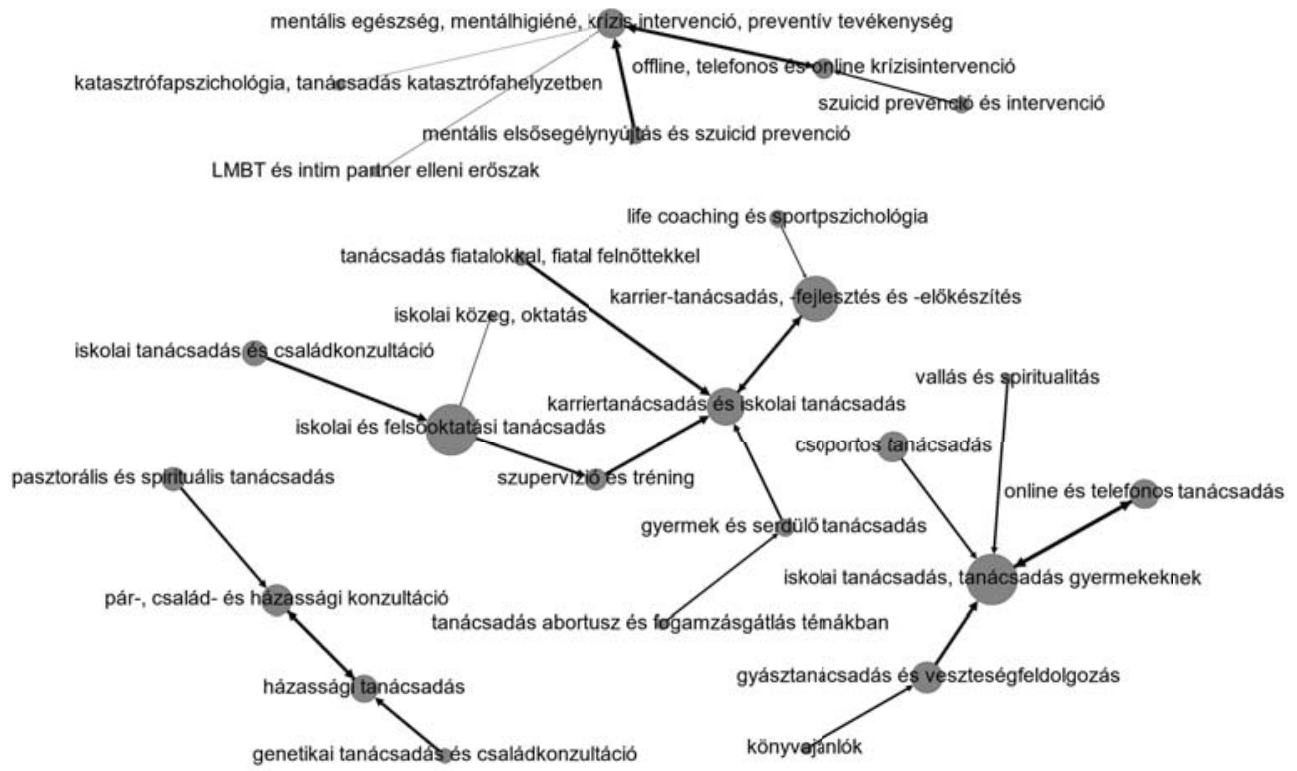

1. ábra. A közösségek legközelebbi kapcsolatain alapuló irányított hálózat (forrás: saját szerkesztés Gephi 0.9.2. szoftverben)

megrajzoltuk - a nódusok távolsága alapján - a közösségek egyszerúsített hálózatát, amelyet az 1. ábra szemléltet. Jelen pontban ezt a közösséghálózatot értelmezzük.

Általánosságban megállapítható, hogy a legtöbb kapcsolódás jól magyarázható, a párok sok esetben egymás kiegészítései vagy határterületei, helyenként pedig témakör-átfedések is vannak. Így például a karrier-tanácsadás és iskolai tanácsadás, valamint a gyermek és serdülő tanácsadás esetében a fiatal korosztály a közös metszet. De kiemelhetjük a házassági tanácsadás és a pár-, család és házassági konzultáció közösségeket is, hiszen mindkettôben megjelenik a házassági tanácsadás témaköre. Egy további példa a mentális egészség, mentálhigiéné, krízisintervenció, preventív tevékenység és a mentális elsôsegélynyújtás és szuicid prevenció közösségek kapcsolata, hiszen ezekben egyaránt kiemelt szerepe van a mentális elsôsegélynyújtásnak. A közösségek gráfja valójában négy fragmentumból áll. E hálózatrészekbe tartozó nódusokat külön táblázatokba foglalva mutatjuk be egyes közösségek tartalmi ismertetését. Terjedelmi korlátok miatt arra nem térünk ki, hogy a 26 közösséget konkrétan mely kulcsszó-kombinációkkal sikerült lefedni, a táblázatokban csupán a lefedettség mértékét tüntetjük fel. A könnyebb értelmezhetôség miatt azonban kiragadunk két közösséget, és ezek példáján keresztül szemléltetjük, hogy mit értünk lefedettség alatt. Az aránylag nagy elemszámú ( $\mathrm{N}=668)$ karrier-tanácsadás, -fejlesztés és -elókészités közösség publikációinak címeiben gyakran ismétlődtek olyan kulcsszavak angol megfelelôi, mint pl. a karrier-tanácsadás, karrierfejlesztés, karrierdöntés, karrierérettség, foglalkozási tanácsadás stb. Ilyen és ehhez hasonló kulcsszavakkal sikerült lefedni a publikációk 80,1\%-át. Más szóval a detektált kulcsszavak olvashatók voltak a közösségbe tartozó szakirodalmak címeinek 80,1\%-ában. Ennél jóval 
élesebben rajzolódott ki a szuicid prevenció és intervenció közösség ( $\mathrm{N}=163)$. A 96,9\%-os lefedettséget itt olyan kulcsszavakkal sikerült kivitelezni, mint pl. öngyilkosság, szuicid prevenció, szuicid viselkedés, szuicid intervenció, posztvenció, szuicidalitás stb.

Az elsố fragmentumban (1. táblázat) egyértelmúen visszaköszön a krízistanácsadás. Több közösségben is találkozhatunk a krízisintervenció, mentális egészség és szuicid prevenció/intervenció témakörökkel. A közösségek e csoportja tulajdonképpen szinkronitást mutat a (magyarországi) tanácsadó szakpszichológus szakirányú továbbképzés egyik specializációs szakaszának, a krízistanácsadásnak a tartalmával. A csoport leginkább központi közössége - a bejövő fokszám alapján - a mentális egészség, mentálhigiéné, krízisintervenció, preventív tevékenység, mely egyben a legnagyobb elemszámú közösség.

1. táblázat. A elsố fragmentumba tartozó közösségek

\begin{tabular}{l|c|c|c}
\hline Közösség neve & Elemszám & Lefedettség & $\begin{array}{c}\text { Bejövó } \\
\text { fokszám }\end{array}$ \\
\hline $\begin{array}{l}\text { mentális egészség, mentálhigiéné, } \\
\text { krízisintervenció, preventív tevékenység }\end{array}$ & 389 & $65,6 \%$ & 4 \\
\hline offline, telefonos és online krízisintervenció & 229 & $83,8 \%$ & 2 \\
\hline $\begin{array}{l}\text { mentális elsôsegélynyújtás és szuicid } \\
\text { prevenció }\end{array}$ & 178 & $74,7 \%$ & 0 \\
\hline szuicid prevenció és intervenció & 163 & $96,9 \%$ & 0 \\
\hline $\begin{array}{l}\text { katasztrófapszichológia, tanácsadás } \\
\text { katasztrófahelyzetben }\end{array}$ & 74 & $91,9 \%$ & 0 \\
\hline LMBT és intim partner elleni erôszak & 36 & $91,7 \%$ & 0 \\
\hline
\end{tabular}

A második fragmentum (2. táblázat) központi témája a fiatalokkal (iskolás korosztállyal és serdülőkkel, fiatal felnôttekkel folytatott) tanácsadás, melyen belül nyilvánvaló aktualitása révén gyakran jelennek meg az iskolai közeggel, illetve karrierrel kapcsolatos kérdések. A három hazai tanácsadó specializáció közül ez a csoportosulás leginkább a munka- és pályatanácsadás specializációval állítható párhuzamba. Ez ugyanakkor kevésbé eklatáns, mint az elôzố esetben, hiszen - bár a pályatanácsadás témaköre jól detektálható - nem találkozhatunk olyan közösséggel, amely deklaráltan a munkahelyi/szervezeti közegben folytatott szakértôi munkát tükrözné vissza (pl. munkakör-gazdagítás, kiválasztás, munkanélküliség, álláskeresés, vezetôi coaching stb.). A csoport központi közössége a karrier-tanácsadás és iskolai tanácsadás, amely nem a legnagyobb elemszámú közösség.

A harmadik fragmentumba (3. táblázat) csupán négy közösség került. Ezekben a házassági, a párkapcsolati és a családkonzultáció a visszatérô elem. Tematikai értelemben némiképp különállónak tûnhet a pasztorális és spirituális tanácsadás közösség. Ám megállapítható, hogy ebbe a közösségbe tartozó szakirodalmak közül a legnagyobb fokszámúak többsége a pasztorális tanácsadás különbözô kontextusait, megjelenési formáit ragadja meg, például pasztorális tanácsadás a házassági tanácsadásban, a családi kontextusban, a gyásztanácsadásban. Ebben az értelemben van létjogosultsága annak, hogy ez a közösség ebbe a csoportba tartozik. A hazai tanácsadó szakpszichológus továbbképzések specializációi közül ez a csoport leginkább a családi és párkapcsolati tanácsadás specializációhoz rokonítható. Ebben a csoportban két központi közösség 
2. táblázat. A második fragmentumba tartozó közösségek

\begin{tabular}{l|c|c|c}
\hline Közösség neve & Elemszám & Lefedettség & $\begin{array}{c}\text { Bejövő } \\
\text { fokszám }\end{array}$ \\
\hline iskolai és felsốoktatási tanácsadás & 777 & $70,3 \%$ & 2 \\
\hline karrier-tanácsadás, -fejlesztés és -elókészítés & 668 & $80,1 \%$ & 2 \\
\hline karrier-tanácsadás és iskolai tanácsadás & 532 & $72,6 \%$ & 4 \\
\hline iskolai tanácsadás és családkonzultáció & 318 & $60,1 \%$ & 0 \\
\hline szupervízió és tréning & 257 & $65,8 \%$ & 1 \\
\hline gyermek- és serdülő-tanácsadás & 192 & $79,2 \%$ & 1 \\
\hline life coaching és sportpszichológia & 171 & $79,5 \%$ & 0 \\
\hline tanácsadás fiatalokkal, fiatal felnóttekkel & 133 & $79,7 \%$ & 0 \\
\hline tanácsadás abortusz és fogamzásgátlás & 67 & $86,6 \%$ & 0 \\
témákban & & & 0 \\
\hline iskolai közeg, oktatás & 18 & $88,9 \%$ & 0 \\
\hline
\end{tabular}

3. táblázat. A harmadik fragmentumba tartozó közösségek

\begin{tabular}{l|c|c|c}
\hline Közösség neve & Elemszám & Lefedettség & $\begin{array}{c}\text { Bejövó } \\
\text { fokszám }\end{array}$ \\
\hline pár-, család- és házassági konzultáció & 419 & $67,8 \%$ & 2 \\
\hline házassági tanácsadás & 358 & $82,7 \%$ & 2 \\
\hline pasztorális és spirituális tanácsadás & 292 & $79,8 \%$ & 0 \\
\hline genetikai tanácsadás és családkonzultáció & 140 & $64,3 \%$ & 0 \\
\hline
\end{tabular}

4. táblázat. A negyedik fragmentumba tartozó közösségek

\begin{tabular}{l|c|c|c}
\hline Közösség neve & Elemszám & Lefedettség & $\begin{array}{c}\text { Bejövó } \\
\text { fokszám }\end{array}$ \\
\hline iskolai tanácsadás, tanácsadás gyermekeknek & 759 & $63,9 \%$ & 4 \\
\hline gyásztanácsadás és veszteségfeldolgozás & 427 & $67,2 \%$ & 1 \\
\hline csoportos tanácsadás & 415 & $69,9 \%$ & 0 \\
\hline online és telefonos tanácsadás & 389 & $60,2 \%$ & 1 \\
\hline könyvajánlók & 83 & $83,9 \%$ & 0 \\
\hline vallás és spiritualitás & 65 & $64,6 \%$ & 0 \\
\hline
\end{tabular}

azonosítható, ezek egyben a legnagyobb elemszámú közösségek a csoportban: a pár-, család-és házassági konzultáció és a házassági tanácsadás.

A negyedik fragmentum (4. táblázat) tartalmilag igencsak eklektikus. Ebben az esetben nehéz lenne kiemelni egyetlen, ismétlôdô témakört. A nódusok méretébôl, illetve az élek irányából látszik, hogy egyértelmúen az iskolai tanácsadás, tanácsadás gyermekeknek közösség a csoportosulás központi közössége.

A fent bemutatott közösségekben a legtöbb esetben visszaköszönnek azok a kulcsszavak, melyekkel az adatgyújtés megkezdődött (pl. gyásztanácsadás, karrier-tanácsadás stb.). A hagyományos, személyes tanácsadási formák mellett egészen nagy szelet jutott a tanácsadás online és telefonos formáinak. Ez szinkronban van Prochaska és Norcross (2011) azon, korábbi elképzelésével, miszerint a pszichoterápiában új tech- 
nológiák alkalmazása is teret fog nyerni - ez pedig meglátásunk szerint vonatkoztatható a nem pszichológiai konzultációkra is. Izgalmas eredmény, hogy feltérképezhetôk voltak olyan közösségek is, melyekre vonatkozóan nem volt célzott keresés, és kizárólag a hálózatelemzéshez szükséges adatok „hólabda” módszerszerú gyújtésének köszönhetôen kerültek végül fókuszba. Ilyen módon lett például önálló közösség a pasztorális és spirituális tanácsadás is, amely megerôsíti azt a tényt, hogy a gyakorló szakemberek egyre több spirituális és vallásos tartalmat építenek be szakmai eszközkészletükbe (Prochaska és Norcross, 2011). Új - eredetileg nem keresett - területként emelkedett ki az abortusz és fogamzásgátlás témájú tanácsadás, valamint az LMBT és az intim partner elleni erôszak témaköre. Úgy gondoljuk, hogy mindezek önmagukban alátámasztják a hálózatelemzés - mint módszertani eszköz - hasznosságát.

Összegezve - a közösségek hálózatának megrajzolásával - négy fö hálózatfragmentumot kaptunk, melyek a pszichológiai tanácsadás egyfajta „világtérképének” is tekinthetôk, amennyiben az alhálózatokra mint „földrészre” tekintünk. Ezek közül három közösségcsoportosulás többé-kevésbé jól megfeleltethető a magyarországi tanácsadó szakpszichológus szakirányú továbbképzés specializációinak - ezáltal tulajdonképpen validálja is a szakterület ilyen logikájú szegmentálását. Összességében megállapítható az is, hogy a gyújtött szakirodalmak egyértelmúen a célcsoport, illetve a pszichológiai tanácsadás kontextustípusai mentén voltak kategorizálhatók. Nem kaptunk ugyanis olyan közösségeket, amelyek például a konzultáció folyamatának egy-egy lépésérôl szólnak (pl. kapcsolatépítés vagy problémafeltárás), vagy azon pszichés funkciók alapján válnak szét, melyek múködési színvonalának megismerése alapvetô jelentôségú a tanácsadói munkában, például kötôdés, bizalom, intimitás (ld. Kissné Viszket és Mogyorósy, 2019).

\section{KORLÁTOK, KITEKINTÉS}

A fenti eredmények mellett szükségesnek érezzük felhívni a figyelmet néhány limitációra. Ezek közül az egyik leginkább lényeges hangsúlyozni a tényt, hogy az adatgyújtés kizárólagosan a ResearchGate adatbázisára fókuszált, mi több a hálózat kirajzolása azon alapult, hogy az egyes publikációk linkjeinél milyen további szakirodalmak jelennek meg ajánlott publikációként. Adja magát tehát a kérdés, hogy az ilyen módon feltárt és kirajzolt kapcsolatrendszer mennyiben szól a pszichológiai tanácsadás alrendszereinek kapcsolatáról, és mennyiben a ResearchGate ajánlórendszerérôl. Erre a kérdésre sajnos nem tudjuk a választ, de annyi biztos, hogy utóbbi is valamennyire hatással van a kapott eredményekre. Úgy véljük, hogy a hálózatelemzés módszere még pontosabb eredményeket kínálna, amennyiben több weboldal adatbázisára együttesen építene az adatgyújtés. Amellett, hogy így szélesebb merítés biztosítható, némiképp ki lehetne küszöbölni az ajánlórendszer hatását is, melynek logikája weboldalanként többé-kevésbé eltérô. Ebben az esetben olyan weboldalakra kellene összpontosítani, melyek - a ResearchGate-hez hasonlóan - megneveznek ajánlott szakirodalmakat az egyes publikációk linkjeinél (pl. SAGE Journals, ScienceDirect stb.). Ezzel azonban majd a különbözó weboldalakról származó információk összekapcsolásának problémáját is meg kell oldani (hiszen az ajánlási linkek mindig az aktuális weboldalon be- 
lüli kapcsolatokat rejtenek). Azt gondoljuk, hogy erre a legalkalmasabb kulcsváltozó a DOI (Digital Object Identifier). Ez ugyanis egy egyedi és állandó azonosító.

További limitációként tartjuk számon azt, hogy a szakirodalmak felrajzolt hálózatában egyetlen módszerrel kiviteleztük a nódusok csoportosítását, közösségekbe rendezését, mégpedig egy olyan modularitásoptimalizáló algoritmussal, amely a Gephi nevú szoftverben is elérhetô. Fontos kiemelni, hogy több közösségdetekciós algoritmus is ismert (pl. Louvain, Leiden, Surprise, Walktrap stb.), így további mélységet jelentett volna a jelen tanulmánynak, ha több ilyen módszert is felvonultatunk.

Összességében úgy gondoljuk, hogy az esettanulmányként bemutatott eredményeket kellố kritikai szemlélettel kell kezelni. Az elsôdleges és legfontosabbnak tartott eredményünk a módszertanhoz kötôdik, ehhez képest másodlagos, de kétségkívül könnyebben megragadható, illetve átlátható ennek gyakorlati alkalmazásaként kapott eredményünk a tanácsadás pszichológiájának lehetséges taxonómiájáról. A felvázolt módszertani újítás lényege a web-scraping és a hálózatelemzés módszereinek kombinálása, amely tulajdonképpen tartalomtól függetlenül megismételhetô, használható a legkülönfélébb szakterületek szakirodalom-gyuujtése során. Ennek segítségével az adott kutatási terület eddigi eredményei alapján empirikus úton is validálható vagy módosítható lehet az egyébként sok esetben csak intuitív alapokon nyugvó fogalmi taxonómia, rendszertan.

Szélesebb perspektívában gondolkodva a pszichológia egészére tekintve a bemutatott módszertan segítségével lényegében minden nagyobb szakterületén hasonló módon feltérképezhetôvé válhatna a fogalmi hálózatok struktúrája. Annak érdekében, hogy az egyes szakterületek ne elszigetelt territóriumok mintájára, vagy zárt, olykor belterjes alakzatokként múködjenek, szükség lenne a közöttük lévô kapcsolódási pontok, átfedések, esetleg szinergiák szisztematikus feltárására. Mindez - még ha csak áttételesen is, de - reményeink szerint talán segíthetné a szakmai területek közötti kapcsolódás, együttmúködés kiteljesedését.

\section{IRODALOM}

Bagdy, E. (2009). Pszichoterápia, tanácsadás, szupervízió, coaching: azonosságok és különbségek. In Kulcsár, É., Tanácsadás és terápia (pp. 53-77). Budapest: ELTE Eötvös Kiadó.

Barabási, A.-L. (2016). A hálózatok tudománya. Budapest: Libri Kiadó.

Bastian, M., Heymann, S., \& Jacomy, M. (2009). Gephi: An Open Source Software for Exploring and Manipulating Networks. Association for the Advancement of Artificial Intelligence (www.aaai. org). Letöltve: 2020. 10. 22-én: https://gephi.org/publications/gephi-bastian-feb09.pdf

Bene, M. (2016). Kommunikációs hálózatok és politikai közösség. Hálózatelemzési módszerek alkalmazása a politikai kommunikáció történetének kutatásában. Politikatudományi Szemle, $25,48-73$.

Berta, S. (2012). Sikeres a ResearchGate, a tudósok közösségi portálja. Letöltve: 2020. 12. 02-án: https://sg.hu/cikkek/it-tech/92588/sikeres-a-ResearchGate-a-tudosok-kozossegi-portalja

Blondel, V. D., Guillaume, J. L., Lambiotte, R., \& Lefebvre, E. (2008). Fast unfolding of communities in large networks. Journal of Statistical Mechanics: Theory and Experiment, 10, 1-12. 
Boote, D. N., \& Beile, P. (2005, August/September). Scholars before researchers: On the centrality of the dissertation literature review in research preparation. Educational Researcher, 34(6), 3-15.

Buda, B. (2009). A lelki segítés alapkérdései - A tanácsadás és a pszichoterápia struktúrái és feltételei. In Kulcsár, É., Tanácsadás és terápia (pp. 11-51). Budapest: ELTE Eötvös Kiadó.

Caldarelli, G. (2020). A perspective on complexity and networks science. Journal of Physics: Complexity, 1(2), 021001.

Cherven, K. (2015). Mastering Gephi Network Visualization. Birmingham: Packt Publishing.

Corsini, R. J. (1981). Handbook of innovative psychotherapies. New York: Wiley.

Csermely, P. (2005). A rejtett hálózatok ereje. Hogyan stabilizálják a világot a gyenge kapcsolatok? Budapest: Vince Kiadó.

Csermely, P. (2020). Hálózatok - Mire alkalmasak, mire nem és hogyan tudnak tanulni? In Balázs, G., Imrényi, A., \& Simon, G. (Eds), Hálózatkutatás. Hálózatok a nyelvben. Budapest: Magyar Szemiotikai Társaság.

Fonyó, I., \& Pajor, A. (2000). Fejezetek a konzultáció pszichológiájának témaköréból. Budapest: Profession.

Giczi, J., \& Szôke, K. (2017). Hivatalos statisztika és a Big Data. Statisztikai Szemle, 95(5), 461-490.

Glass, G. V. (1976). Primary, Secondary, and Meta- Analysis. Educational Researcher, 5(1), 3-8.

Herink, R. (1980). The Psychotherapy Handbook. New York: New American Library.

Isinkaye, F. O., Folajimi, Y. O., \& Ojokoh, B. A. (2015). Recommendation systems: Principles, methods and evaluation. Egyptian Informatics Journal, 16, 261-273.

Kissné Viszket, M., \& Mogyorósy, Zs. (2019). A Pszichológiai Tanácsadás Szakmai Alapprotokollja 2017-2018. Budapest: ELTE Eötvös Kiadó.

Khan, B. S., \& Niazi, M. A. (2017). Network Community Detection: A Review and Visual Survey. Letöltve: 2020. 04. 12-én: https://arxiv.org/ftp/arxiv/papers/1708/1708.00977.pdf

Mayer-Schönberger, V., \& Cukier, K. (2014). BIG DATA. Forradalmi módszer, amely meguáltoztatja munkánkat, gondolkodásunkat és egész életünket. Budapest: HVG Könyvek.

Mertens, D. M. (2010). Research and Evaluation in Education and Psychology: Integrating Diversity With Quantitative, Qualitative, and Mixed Methods. London: Sage.

Prochaska, J. O., \& Norcross, J. C. (2011). A pszichoterápia rendszerei. Összehasonlító elemzés. Budapest: Animula.

$\mathrm{Pu}, \mathrm{P} .$, Chen, L., \& Hu, R. (2011). A user-centric evaluation framework for recommender systems. In Proceedings of the fifth ACM conference on Recommender Systems (RecSys'11) (pp. 157-164). New York: ACM.

Richardson, L. (2019). Beautiful Soup Documentation. Letöltve: 2020. 11. 19-én: https://readthedocs.org/projects/beautiful-soup-4/downloads/pdf/latest/

Sebestyén, T. (2011). Hálózatelemzés a tudástranszferek vizsgálatában - régiók közötti tudáshálózatok struktúrájának alakulása Európában. Statisztikai Szemle, 89(6), 667-697.

Swinnen, G. (2005). Tanuljunk meg programozni Python nyelven. Letöltve: 2020. 11. 19-én: https:// mek.oszk.hu/08400/08435/08435.pdf

Szemán, D., \& Karner, O. (2017). Tanácsadási modellek a felsôoktatási tanácsadásban - a hatalkalmas modell tapasztalatai. Alkalmazott Pszichológia, 17(4), 105-128.

Szokolszky, Á. (2004). Kutatómunka a pszichológiában. Budapest: Osiris Kiadó.

Vargha, A. (1984). A pszichológia és a matematika kapcsolata pszichológiai nézópontból. $M a-$ gyar Pszichológiai Szemle, 41, 457-476. 


\section{PROCESSING PSYCHOLOGICAL LITERATURE WITH THE METHODOLOGY OF NETWORK-ANALYSIS: A POTENTIAL TAXONOMY OF COUNSELING PSYCHOLOGY}

\section{CZABÁN, CSABA - NAGYBÁNYAI-NAGY, OLIVÉR}

Examining and understanding the different fie lds and areas of psychological science and methodology is a complex, time-consuming task, that invariably requires collecting and processing scientific literature. When deciding on how to process comprehensive scientific literature, we can either choose between (qualitative) narrative reviews or (quantitative) meta-analysis.

The network-analysis methodology is an efficient way of supporting the exploration, research and integration of a specific fiel d's terminology, not only in terms of global understanding, but also in terms of helping to orient towards new, research-focused subareas.

Our study introduces this methodology using an example from counseling psychology. First it reveals the process of automated data collection (web scraping), then it shows how to process this data by using network-analysis.

As a result, we were able to determine and draw patterns between the key topics of counseling psychology in scientific literature in the fiel $d$ of modularity-based community detection. Altogether we obtained four main network fractures, whereas these fig uratively speaking „continents” could build the fundamentals of the counseling psychology world-map.

Keywords: network-analysis, network research, community detection, modularity, scientific literature collection, scientificliteratur e review, counseling psychology

A cikk a Creative Commons Attribution 4.0 International License (https://creativecommons. org/licenses/by/4.0/) feltételei szerint publikált Open Access közlemény, melynek szellemében a cikk bármilyen médiumban szabadon felhasználható, megosztható és újraközölhetô, feltéve, hogy az eredeti szerzô és a közlés helye, illetve a CC License linkje és az esetlegesen végrehajtott módosítások feltüntetésre kerülnek. (SID_1) 